\title{
Renal Cell Carcinoma with Skull Base Metastasis Preceded by Paraneoplastic Signs in a Chronic Hemodialysis Patient
}

\author{
Kazunori Endo, Ryo OKano, Yutaka KuRodA*, Shigeki YAMAdA** and Kaoru TABeI*
}

\begin{abstract}
A 59-year-old man who had received chronic hemodialysis developed left occipital pain and hypoglossal nerve palsy. He was diagnosed as having skull base metastasis from renal cell carcinoma related to acquired cystic kidney. Retrospective analysis revealed the patient had had elevated serum C-reactive protein and alkaline phosphatase levels before the symptoms appeared. Radiotherapy to the skull base relieved the pain. Finally he died with generalized metastases. Serum interleukin-6 levels measured during admission had been elevated, and interleukin-6 mRNA was detected in the autopsy specimen of renal cell carcinoma. Interleukin-6 might be involved in the etiology of paraneoplastic signs.
\end{abstract}

(Internal Medicine 40: 924-930, 2001)

Key words: acquired cystic kidney, C-reactive protein, alkaline phosphatase, interleukin-6, hypoglossal nerve palsy

\section{Introduction}

Renal cell carcinoma is not uncommonly encountered in patients receiving long-term hemodialysis. It is mostly related to the presence of multiple renal cysts, in the condition known as acquired cystic disease of the kidney (1-3). Renal cell carcinoma is recognized as the internist's tumor, because of the diverse and often obscure presenting signs and symptoms associated with paraneoplastic systemic effects (4). Interleukin-6 is thought to be partially involved in the mechanism (5). Moreover, renal cell carcinoma is known to metastasize to bones frequently, although skull base metastasis causing unilateral hypoglossal nerve palsy has not been described before as a presenting symptom. We present a case of renal cell carcinoma from acquired cystic disease of the kidney in a chronic hemodialysis patient. The patient had skull base metastasis with uni- lateral hypoglossal nerve palsy, preceded by elevated serum $\mathrm{C}$-reactive protein and alkaline phosphatase levels.

\section{Case Report}

A 59-year-old man was admitted to our hospital in March 1998 with a history of left occipital pain for 6 months and dysarthria for 5 months. At the age of 24 years, he had been diagnosed as having chronic glomerulonephritis, and he had received chronic maintenance hemodialysis from the age of 39 years. He smoked 5 cigarettes daily, and the family history included breast cancer in his sister and lung cancer in his brother. He had received maintenance hemodialysis three times a week for 20 years. Since February 1995 his serum C-reactive protein (CRP) and alkaline phosphatase (ALP) levels had been elevated and increased gradually in the absence of symptoms (Fig. 1). Since October 1997, the patient had suffered left occipital pain and stiffness in his left shoulder. His headache was not pulsating but persistent. He had occasionally had slight fever of unknown origin, and had had dysarthria and difficulty moving his tongue since November 1997. Magnetic resonance imaging (MRI) of the brain performed at another hospital in December 1997 had revealed no abnormal findings, and he had been given analgesics for the pain. In February 1998, his symptoms worsened and he became bedridden because of the pain. He was admitted to our hospital in March 1998.

On admission, physical examination revealed clear consciousness and good orientation. The patient was unable to sustain a sitting position because of his pain. Both eyelids were puffy, and anemia was present. No abdominal masses were palpable, and the prostate was normal for his age on digital examination. Neurological examination revealed normal findings, apart from left hypoglossal nerve palsy, revealed as tongue deviation and atrophy.

Laboratory data on admission (Table 1) revealed uremia, anemia of renal origin, and elevated serum ALP at $457 \mathrm{U} / l$, dominated type II (77\%) and with a reduced level of type III (3.5\%). The serum $\gamma$-glutamyl transpeptidase level was also slightly elevated at $79 \mathrm{U} / l$, but aminotranferase levels were

From the Department of General Medicine, *the Division of Nephrology and **the Division of Pathology, Omiya Medical Center, Jichi Medical School, Saitama

Received for publication November 24, 2001; Accepted for publication March 19, 2001

Reprint requests should be addressed to Dr. Kazunori Endo, the Department of General Medicine, Omiya Medical Center, Jichi Medical School, 1-847 Amanuma-cho, Saitama 330-8503 
normal. The CRP level, erythrocyte sedimentation rate and ferritin level were markedly elevated, indicating an inflammatory state. Examination of tumor markers showed a very slightly elevated level of squamous cell carcinoma-related antigen, but all others were normal. Cerebrospinal fluid (CSF) analysis gave normal results, except for an elevated protein level of $82.4 \mathrm{mg} /$ $\mathrm{dl}$, and CSF cytology was also normal. Bacteriologic cultures of blood and CSF specimens were negative, and a tuberculin

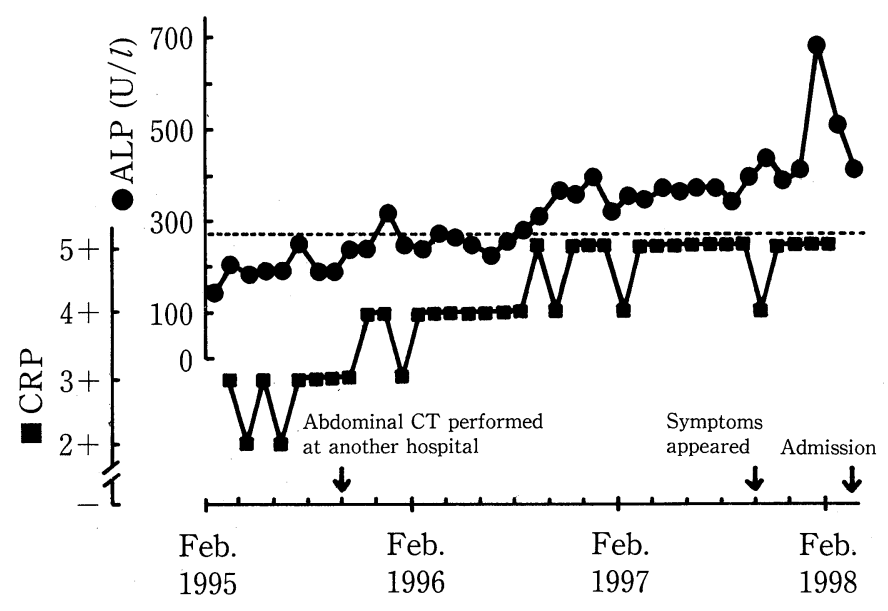

Figure 1. Clinical course of $\mathrm{C}$-reactive protein and alkaline phosphatase before admission. CRP: C-reactive protein, ALP: Alkaline phosphatase, CT: Computed tomography, Dotted line: upper limit of normal range of ALP. skin test was negative.

Computed tomography (CT) of the brain demonstrated remarkable destruction of the bone of the skull base, extending from the clivus to the left lateral occipital bone (Fig. 2). MRI of the brain revealed a mass of low signal intensity on T1weighted imaging in the same region (Fig. 2). Since skull base metastasis was strongly suspected, we performed malignancy survey examinations. These included a chest X-ray, CT scans of the chest and abdomen, ultrasound study of the abdomen, upper gastrointestinal endoscopy, colonic endoscopy, gallium67 scintigraphy and a radionuclide bone scan of the whole body. However, these tests revealed no abnormal findings, apart from bilateral multiple cystic kidneys, hepatosplenomegaly, and slightly increased tracer activity at the left skull base. Therefore, tumors likely to originate in the bone at the base of the skull, such as chondroma, chondrosarcoma, meningioma and malignant lymphoma, as well as osteomyelitis of the skull base, were considered as differential diagnoses. Surgical biopsy was needed for an accurate diagnosis, but neurological surgery staff judged that the risks of performing this procedure in this patient were too high.

Therefore, various types of antibiotics were administered, followed by anti-tuberculosis agents, but they had no effect. Chemotherapy with cyclophosphamide, doxorubicin, vincristine and prednisone was given on suspicion of malignant lymphoma, but there was no remarkable change. The patient's general condition worsened daily.

We then carefully reviewed all data from the earlier examinations. Finally we found a tumor in the lower portion of the right kidney (Fig. 3), which we had considered was residual

Table 1. Laboratory Data on Admission

\begin{tabular}{lrlr}
\hline Hematologic laboratory findings & & Blood chemical values \\
White blood cell count & $4,750 / \mathrm{mm}^{3}$ & Total protein & $6.6 \mathrm{~g} / \mathrm{dl}$ \\
Red blood cell count & $295 \times 10^{4} / \mathrm{mm}^{3}$ & Albumin & $3.0 \mathrm{~g} / \mathrm{dl}$ \\
Hemoglobin & $8.7 \mathrm{~g} / \mathrm{dl}$ & Total bilirubin & $0.3 \mathrm{mg} / \mathrm{dl}$ \\
Hematocrit & $27.9 \%$ & Aspartate aminotransferase & $9 \mathrm{U} / l$ \\
Reticulocyte count & $21 \%$ Clanine aminotransferase & $6 \mathrm{U} / l$ \\
Platelet count & $22.6 \times 10^{4} / \mathrm{mm}^{3}$ & Lactate dehydrogenase & $205 \mathrm{U} / l$ \\
Erythrocyte sedimentation rate & $140 \mathrm{~mm} / \mathrm{h}$ & Alkaline phosphatase & $457 \mathrm{U} / l$ \\
C-reactive protein & $12.2 \mathrm{mg} / \mathrm{dl}$ & (type I: $19 \%$, II: $77 \%$, III: $3.5 \%)$ & $79 \mathrm{U} / l$ \\
Immunologic findings & & $\gamma$-Glutamyl transpeptidase & $87 \mathrm{U} / l$ \\
Immunoglobulin G & $1,298 \mathrm{mg} / \mathrm{dl}$ & Amylase & $35 \mathrm{U} / l$ \\
Immunoglobulin A & $169 \mathrm{mg} / \mathrm{dl}$ & Creatinephosphokinase & $64 \mathrm{mg} / \mathrm{dl}$ \\
Immunoglobulin M & $55 \mathrm{mg} / \mathrm{dl}$ & Blood urea nitrogen & $8.7 \mathrm{mg} / \mathrm{dl}$ \\
Immunoglobulin E & $72 \mathrm{U} / \mathrm{ml}$ & Creatinine & $6.3 \mathrm{mg} / \mathrm{dl}$ \\
Complement 3 & $105 \mathrm{mg} / \mathrm{dl}$ & Uric acid & $141 \mathrm{mEq} / l$ \\
Complement 4 & $72 \mathrm{mg} / \mathrm{dl}$ & Sodium & $99 \mathrm{mEq} / l$ \\
Tumor markers & & Chloride & $5.9 \mathrm{mEq} / l$ \\
Carcino-embryonic antigen & $2.6 \mathrm{ng} / \mathrm{ml}$ & Potassium & $9.5 \mathrm{mg} / \mathrm{dl}$ \\
Squamous cell carcinoma & & Calcium & $6.6 \mathrm{mg} / \mathrm{dl}$ \\
related antigen & $2.3 \mathrm{ng} / \mathrm{ml}$ & Phosphorus & $144 \mathrm{mg} / \mathrm{dl}$ \\
Neuron specific enolase & $6.7 \mathrm{ng} / \mathrm{ml}$ & Total cholesterol & $97 \mathrm{mg} / \mathrm{dl}$ \\
Prostate specific antigen & $2.5 \mathrm{ng} / \mathrm{ml}$ & Glucose & $35 \mu \mathrm{g} / \mathrm{dl}$ \\
& & Serum iron & $1,566 \mathrm{ng} / \mathrm{ml}$ \\
& & Ferritin &
\end{tabular}




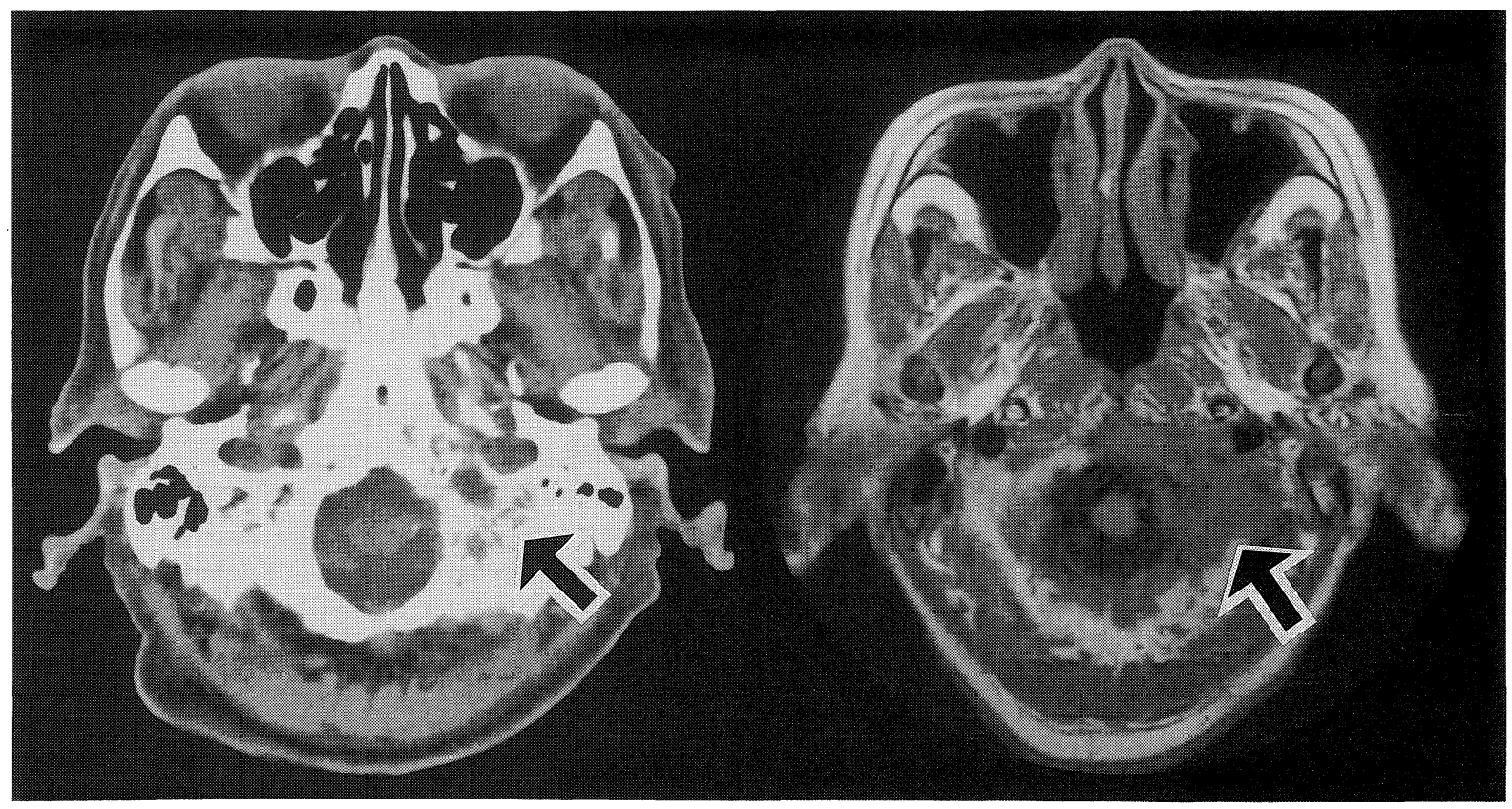

Figure 2. Computed tomography and magnetic resonance imaging of cranial base. Computed tomography (left) revealed remarkable destruction of the bone of the skull base, extending from the clivus to the left lateral occipital bone (arrow). Magnetic resonance imaging (right: T1-weighted) showed a low signal intensity area in the same region (arrow).

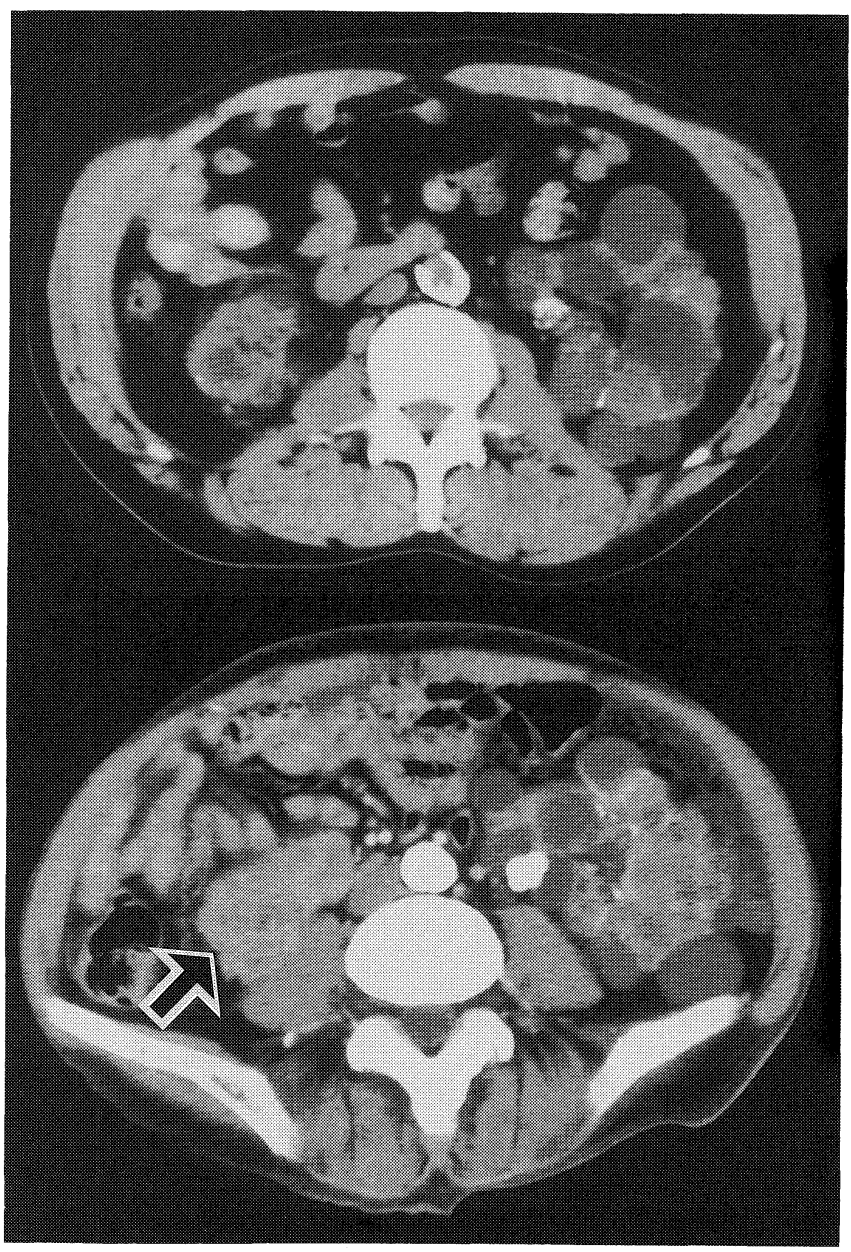

kidney parenchyma. Color-doppler echography revealed bloodflow signs in this tumor. Moreover, an abdominal CT scan performed incidentally at another hospital in October 1995 showed multiple cystic kidneys without the tumor (Fig. 3). We diagnosed skull base metastasis from right renal cell carcinoma derived from acquired renal cysts.

As the general condition of the patient was extremely poor, we decided that it was too dangerous and difficult to perform surgery on the skull base metastasis or kidney tumor. External radiotherapy was conducted to relieve the pain, with a total dose $50 \mathrm{~Gy}$ to the skull base. The therapy was effective for the headache and shoulder stiffness, but the hypoglossal nerve palsy remained unchanged. Brain CT and MRI examinations showed no increase of the tumor size, and the patient was discharged in September 1998. One month later, he was admitted with tumor-related fever, but the fever improved spontaneously. In November he fractured his left upper arm, and a bone X-ray revealed metastasis in the area. The arm fracture was wired under local anesthesia. The patient's general condition deteriorated markedly and he died in December 1998.

Figure 3. Computed tomography of abdomen. Computed tomography (upper) performed incidentally at another hospital in October 1995 revealed multiple cysts of both kidneys at the right lower kidney level. Enhanced computed tomography (lower) taken in March 1998 disclosed multiple cysts and a slightly enhancing area indicating a tumor of the lower portion of right kidney (arrow). 
The autopsy findings revealed multiple cysts of both kidneys, with a yellow, solid tumor, $9 \mathrm{~cm}$ in diameter, located at the lower pole of the right kidney (Fig. 4). Other tumors were also identified at the right renal hilus and the right adrenal portion. At the left lateral margin of the occipital foramen magnum (near the hypoglossal canal) there was a yellow tumor, 2 $\mathrm{cm}$ in diameter, protruding from the bone of the skull base. Histologic examination revealed renal cell carcinoma of clearcell type, G2, in the renal tumor and the skull base tumor. There were also multiple metastases involving the left adrenal gland, the liver, both lungs, the vertebrae and the ribs.

We measured the interleukin-6 (IL-6) levels in serum stored

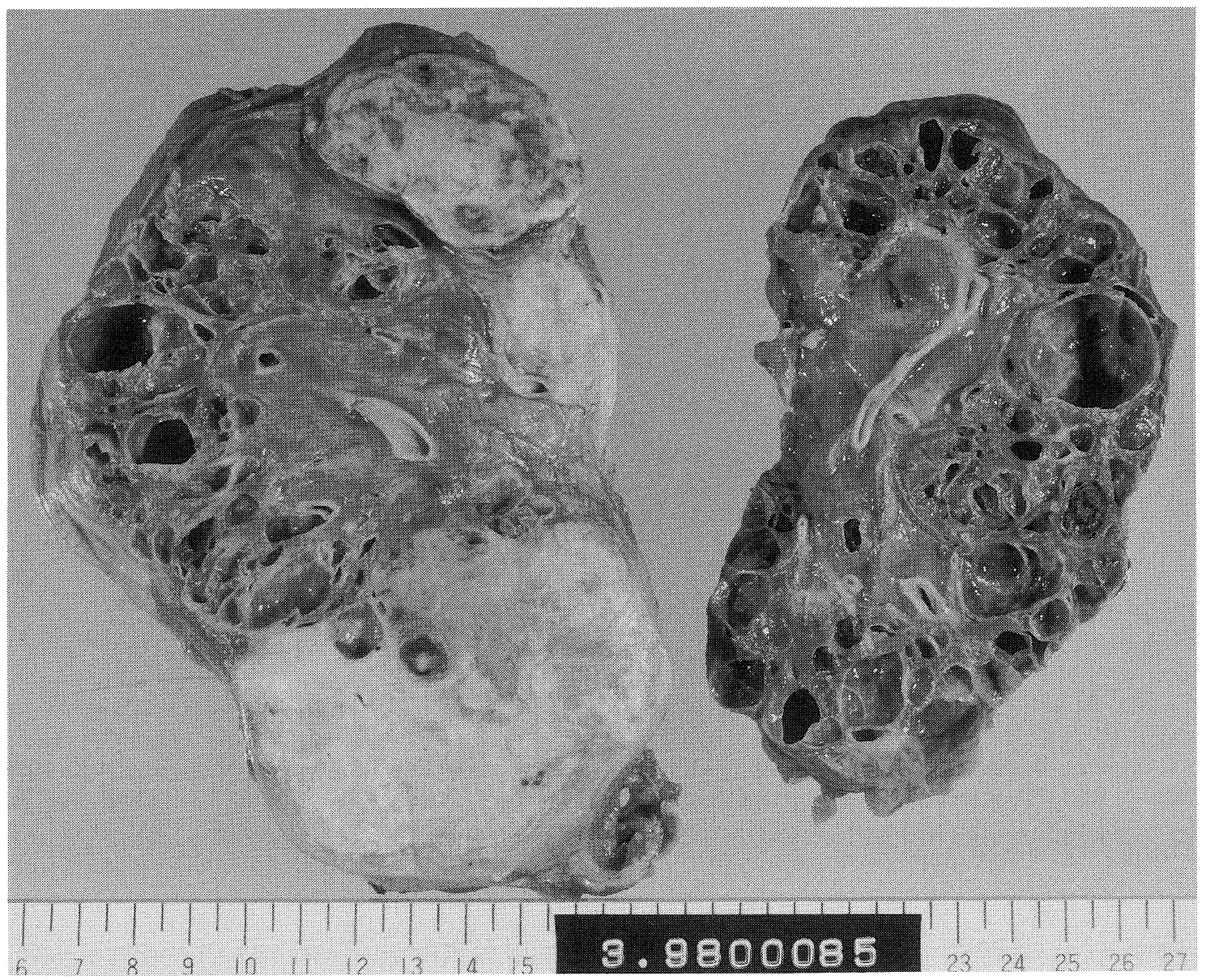

Figure 4. Macroscopic findings of both kidneys at autopsy. The right kidney was enlarged, with multiple cysts, and had yellow, solid tumors at the lower pole, hilus and adrenal portion. The left kidney also had multiple cysts.

Table 2. Clinical Course of Interleukin-6, Inflammatory Signs and Alkaline Phosphatase

\begin{tabular}{lrcccccc}
\hline & \multicolumn{7}{c}{ Radiotherapy } \\
Date & & 1998.4 .3 & 7.10 & 9.3 & 10.19 & 11.25 & 12.8 \\
\hline Interleukin-6* & $(\mathrm{pg} / \mathrm{ml})$ & 24.5 & 39.8 & 72.2 & 249.0 & 237.0 & 3520.0 \\
C-reactive protein & $(\mathrm{mg} / \mathrm{dl})$ & 9.5 & 8.0 & 12.5 & 19.3 & 26.6 & 22.9 \\
Erythrocyte sedimentation rate & $(\mathrm{mm} / \mathrm{h})$ & 118 & 91 & 120 & 146 & 158 & 134 \\
Ferritin & $(\mathrm{ng} / \mathrm{ml})$ & 1,592 & 2,004 & 1,727 & 2,769 & 7,593 & 8,420 \\
Total bilirubin & $(\mathrm{mg} / \mathrm{dl})$ & 0.3 & 0.5 & 0.4 & 0.4 & 0.7 & 2.0 \\
Alkaline phosphatase & $(\mathrm{U} / l)$ & 511 & 1,415 & 862 & 1,985 & 2,999 & 2,177 \\
$\gamma$-Glutamyl transpeptidase & $(\mathrm{U} / l)$ & 109 & 114 & 58 & 71 & 173 & 67 \\
\hline
\end{tabular}

*: normal range $\leqq 4.0 \mathrm{pg} / \mathrm{ml}$. 


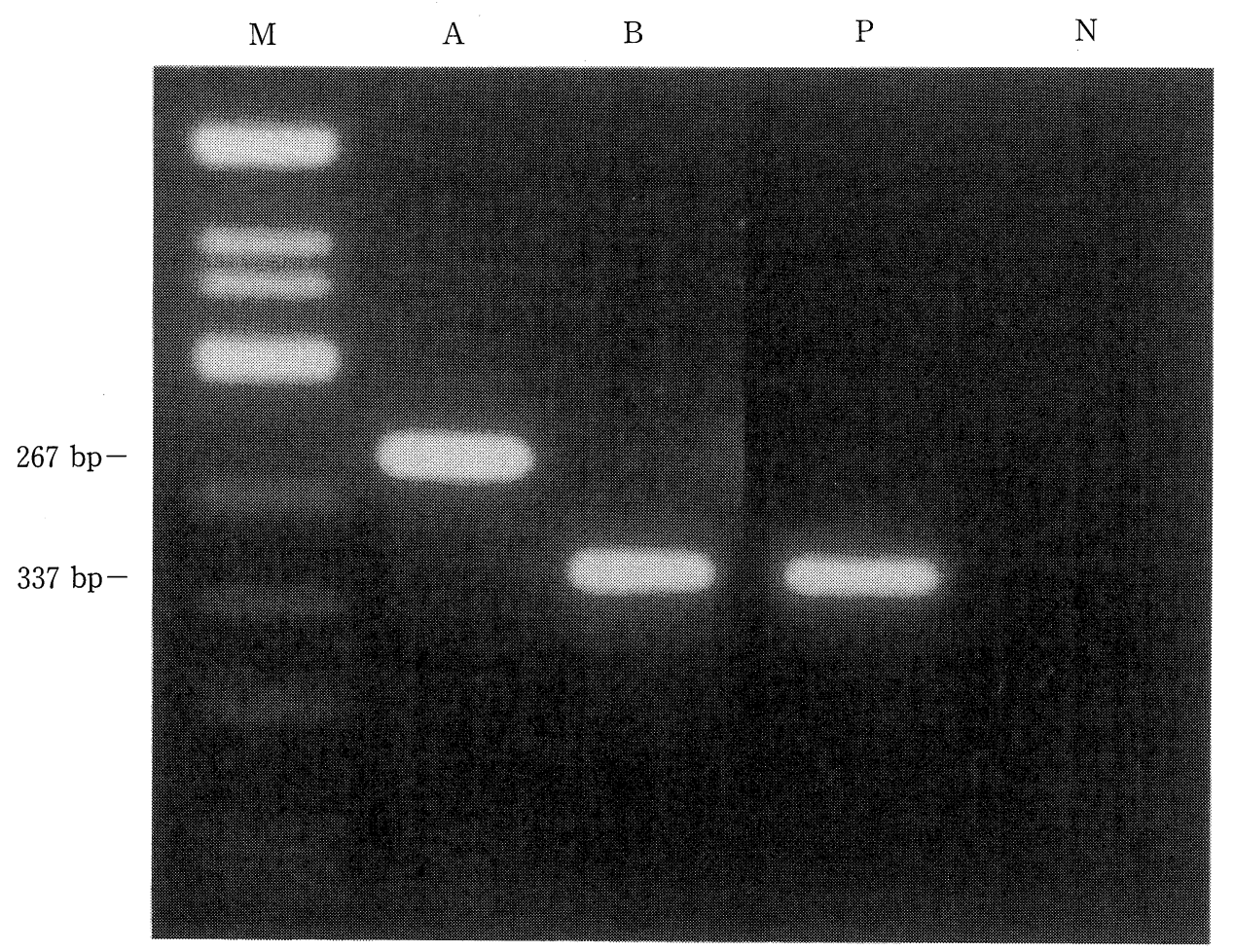

Figure 5. Interleukin-6 (IL-6) mRNA detected in the right renal tumor. Total RNA was extracted from 5 mg samples of the patient's right kidney tumor. Reverse transcriptase-polymerase chain reaction (RT-PCR) was performed to synthesize the cDNA of the IL-6 gene from $1 \mu \mathrm{g}$ total RNA with specific primers (IL-6 forward: $5^{\prime}$ CAGCCCTGAGAAAGGAGACAT-3', IL-6 reverse: $5^{\prime}$-GGAACTGGATCAGGACTTTTGTAC-3'), and was carried out for 35 cycles $\left(95^{\circ} \mathrm{C}\right.$ for $30 \mathrm{~s}, 55^{\circ} \mathrm{C}$ for $30 \mathrm{~s}$, and $72^{\circ} \mathrm{C}$ for $\left.35 \mathrm{~s}\right)$. The PCR product was electrophoresed on 3\% agarose gel, stained with ethidium bromide, and detected with ultraviolet light. Lane M: molecular markers; lane A: $\beta$-actin mRNA as an internal control (337 bp ladder) from the patient; lane B: IL-6 mRNA (267 bp ladder) from the patient; lane $P$ : positive control, lane $N$ : negative control.

from three admissions. The IL-6 levels were elevated and had increased gradually with time (Table 2), as did the CRP and ALP levels. IL-6 mRNA was detected in the right renal tumor by agarose gel electrophoresis with reverse transcriptase-polymerase chain reaction (Fig. 5).

\section{Discussion}

Multiple renal cysts are frequently encountered in chronic hemodialysis patients, and the condition is known as acquired cystic disease of the kidney (ACDK) (1-3). The incidence increases with the duration of hemodialysis. The incidence is $44 \%$ in those who have undergone hemodialysis for less than 3 years, $79 \%$ for more than 3 years of hemodialysis and $90 \%$ for more than 10 years $(2,3)$. The incidence of renal cell carcinoma in hemodialysis patients is thought to be 15 to 18 times higher than that in the general population, because the development of renal cell carcinoma is associated with ACDK (2). There is a high risk of renal cell carcinoma in male dialysis patients with a history of more than 10 years of hemodialysis and enlarged kidneys due to $\operatorname{ACDK}(2,3)$. Almost all dialysis patients with renal cell carcinoma are asymptomatic. If present, symptoms and signs associated with renal cell carcinoma are diverse and often obscure, and there are no known specific serum diagnostic markers for renal cell carcinoma. Therefore, routine ultrasonographic or $\mathrm{CT}$ examinations are recommended for finding renal cell carcinoma in the early stages $(2,3)$. The present patient was definitely in a high-risk group. However, we were unable to interpret the tumor in the lower portion of the right kidney as renal cell carcinoma; instead, it appeared as residual kidney parenchyma. We were able to find the tumor only when we compared our films with earlier CT scans taken at another hospital. Ishikawa (3) recommended that if a patient on long-term dialysis exhibits an area of normal parenchymal density on CT scan, the area should be considered abnormal and suggestive of a renal cell tumor.

Metastasis to the base of the skull often causes characteristic syndromes that are a combination of headache and cranial nerve deficits $(6,7)$. There are 5 clinical syndromes: 1$)$ orbital syndrome, consisting of supraorbital pain, exophthalmos and extraocular paresis; 2) parasellar syndrome, producing unilateral frontal headache and ocular paresis without proptosis; 3 ) 
middle fossa syndrome, causing facial numbness or pain, and sensory loss in the distribution of the trigeminal nerve; 4) jugular foramen syndrome, composed of unilateral occipital or postauricular pain, and evidence of glossopharyngeal, vagus and accessory nerve dysfunction; 5) occipital condyle syndrome, made up of unilateral occipital pain, stiff neck and unilateral hypoglossal nerve palsy. The diagnosis of metastasis to the skull base is often difficult, particularly if the patient is not known to have cancer in other organs (6). The present patient had characteristic signs of the occipital condyle syndrome, and we strongly suspect that he probably had a skull base lesion at an earlier stage, even though MRI performed elsewhere in December 1997 did not reveal the lesion. It is important to know that CT or MRI can demonstrate skull base lesions compatible with the clinical findings in $81 \%$ of cases, but not in all (7).

The most common primary site of skull base metastasis is the breast, followed by the lung and the prostate $(6,7)$. Renal cell carcinoma tends to metastasize to all parts of the body, and bone metastasis is common. Approximately $16 \%$ of renal cell carcinoma metastases to bones are located in the skull (8). However, it is not known what percentage of these occur at the skull base. A metastasis to the skull base causing an isolated unilateral hypoglossal nerve palsy -the occipital condyle syndrome- is unusual $(6,9-13)$. We were unable to find any reference in the English literature to isolated hypoglossal nerve palsy caused by renal cell carcinoma metastasis to the base of the skull (MEDLINE search 1966-2000), although there was one report of renal cell carcinoma presenting as progressive unilateral cranial nerve palsies (Garcin's syndrome) (14).

Reports on radiotherapy to skull base tumors are rare, but suggest that this treatment is useful for relieving symptoms (15). Early treatment provides the best relief. In our patient, earlier diagnosis would have led to earlier pain relief.

Renal cell carcinoma is frequently associated with paraneoplastic findings (4). It is especially associated with inflammatory signs such as fever, increased erythrocyte sedimentation rate and increased serum acute-phase protein levels, and non-metastatic reversible hepatic dysfunction with increased ALP of the so-called Stauffer's syndrome $(5,16,17)$. The mechanisms responsible for these paraneoplastic signs remain poorly understood, but IL-6 has recently been suggested to play a causative role (5). Administration of recombinant IL-6 produces an increase in serum levels of acute-phase protein and ALP (18). Renal-carcinoma cell lines produce IL-6 in vitro, and about $50 \%$ of patients with metastatic renal cell carcinoma have increased levels of serum IL-6 (19-21). Paraneoplastic signs are suppressed by anti-IL-6 antibody (5). The present patient's CRP and ALP levels increased a few years before symptoms appeared. IL-6 was detected in his serum during admission, and IL-6 mRNA was detected in renal cell carcinoma tissue taken at autopsy. Therefore, we speculate that IL6 might have been associated with the elevated CRP and ALP levels in this patient.

CRP, ALP and IL-6 levels are also known to be elevated in hemodialysis patients. The literature reports a mean CRP concentration in hemodialysis patients of $0.747 \mathrm{mg} / \mathrm{dl}$ (range 0.2 to $4.24 \mathrm{mg} / \mathrm{dl}$ ) (22). Another report maintained that $47 \%$ of hemodialysis patients without evidence of inflammation had CRP levels within the normal range (less than $1 \mathrm{mg} / \mathrm{dl}$ ); the remaining 53\% had levels between 1 and $5 \mathrm{mg} / \mathrm{dl}$ (23). A CRP level of more than $5 \mathrm{mg} / \mathrm{dl}$ has proved highly suggestive of a significant inflammatory process (23). Therefore, the fact that the CRP levels of the present patient had been $3+\sim 4$ (equal to $3 \sim 11 \mathrm{mg} / \mathrm{dl}$ ) from a few years before symptoms appeared should have suggested an inflammatory disease.

Although the serum ALP level was elevated in our patient, ALP is known to be elevated in dialysis patients, and the level of bone ALP isoenzyme (type III) is related to the severity of dialysis bone disease (24). Metabolic bone disease is a common complication of chronic renal failure. However, in the present patient, liver-derived isoenzyme was dominant and bone isoenzyme was at low levels. Therefore, his elevated ALP level was related not to dialysis, but possibly to liver disease. There were no liver metastases or evidence of hepatobiliary obstruction on CT and ultrasound studies of the abdomen on first admission. Non-metastatic hepatic dysfunction, associated with renal cell carcinoma has been described $(4,16,17)$. The elevated ALP level might have resulted from paraneoplastic mechanisms.

In hemodialysis the serum IL-6 level is known to be elevated (25-27). Therefore, the elevated serum IL-6 level in the present patient would not necessarily have indicated renal cell carcinoma, although we detected IL-6 mRNA in the autopsy specimen.

This was an unusual case of a hemodialysis patient who had symptoms of skull base metastasis as initial signs of renal cell carcinoma in acquired cystic disease of the kidney, and who also had chronic inflammatory changes with elevated ALP preceding the onset of symptoms, as part of a paraneoplastic signs.

Acknowledgements: We thank Dr. Masaharu Kajiya, Hasuda Clinic, for providing valuable information of the patient.

\section{References}

1) Dunnill MS, Millard PR, Oliver D. Acquired cystic disease of the kidneys: a hazard of long-term intermittent maintenance haemodialysis. $J$ Clin Pathol 30: 868-877, 1977.

2) Ishikawa I. Acquired cystic disease and renal tumors in long-term dialysis patients. in: Complications of Long-term Dialysis. Brown EA, Parfrey PS, Eds. Oxford University Press, Oxford, 1999: 145-169.

3) Ishikawa I. Uremic acquired renal cystic disease, natural history and complications. Nephron 58: 257-267, 1991.

4) Garnick MB, Richie JP. Renal Neoplasia. in: The Kidney. 5th ed. Brenner BM, Ed. WB Saunders, Philadelphia, 1996: 1959-1977.

5) Blay JY, Rossi JF, Wijdenes J, et al. Role of interleukin-6 in the paraneoplastic inflammatory syndrome associated with renal-cell carcinoma. Int J Cancer 72: 424-430, 1997.

6) Greenberg HS, Deck MDF, Vikram B, Chu FCH, Posner JB. Metastasis to the base of the skull: clinical findings in 43 patients. Neurology 31 : 530-537, 1981.

7) Jansen BPW, Pillay M, de Bruin HG, van den Bent MJ, Vecht ChJ, Sillevis Smitt PAE. ${ }^{99 \mathrm{~m}} \mathrm{Tc}-\mathrm{SPECT}$ in the diagnosis of skull base metastasis. Neurology 48: 1326-1330, 1997.

8) Swanson DA, Orovan WL, Johnson DE, Giacco G. Osseous metastases secondary to renal cell carcinoma. Urology 18: 556-561, 1981. 


\section{ENDO et al}

9) Fukumoto M, Osaki Y, Yoshida D, et al. Dual-isotope SPECT diagnosis of a skull-base metastasis causing isolated unilateral hypoglossal nerve palsy. Ann Nucl Med 12: 213-216, 1998.

10) Shiraishi T, Yanagida $H$, Takada $K$, Yasuhara Y. Unusual cranial metastasis from hepatoma presenting as isolated unilateral hypoglossal nerve paresis. Neurol Med Chir (Tokyo) 32: 166-168, 1992.

11) Brillman J, Valeriano J, Adatepe MH. The diagnosis of skull base metastases by radionuclide bone scan. Cancer 59: 1887-1891, 1987.

12) Ransom DT, Dinapoli RP, Richardson RL. Cranial nerve lesions due to base of the skull metastases in prostate carcinoma. Cancer 65: 586-589, 1990.

13) Moris G, Roig C, Misiego M, Alvarez A, Berciano J, Pascual J. The distinctive headache of the occipital condyle syndrome: a report of four cases. Headache 38: 308-311, 1998.

14) Mubaidin SI, Sunna JB, Beiruti MA, Shennak MM, Ayoub MS. Renal cell carcinoma presenting as Garcin's syndrome. J Neurol Neurosurg Psychiatry 53: 613-614, 1990.

15) Vikram B, Chu FCH. Radiation therapy for metastases to the base of the skull. Radiology 130: 465-468, 1979.

16) Stauffer MH. Nephrogenic hepatosplenomegaly. Gastroenterology 40: 694, 1961 (Abstract).

17) Walsh PN, Kissane JM. Nonmetastatic hypernephroma with reversible hepatic dysfunction. Arch Intern Med 122: 214-222, 1968.

18) Weber J, Gunn H, Yang J, et al. A phase I trial of intravenous interleukin6 in patients with advanced cancer. J Immunother Emphasis Tumor Immunol 15: 292-302, 1994.
19) Takenawa J, Kaneko Y, Fukumoto M, et al. Enhanced expression of interleukin-6 in primary human renal cell carcinomas. J Natl Cancer Inst 83: 1668-1672, 1991.

20) Blay JY, Negrier S, Combaret V, et al. Serum level of interleukin 6 as a prognosis factor in metastatic renal cell carcinoma. Cancer Res 52: 33173322, 1992.

21) Walther MM, Johnson B, Culley D, et al. Serum interleukin-6 levels in metastatic renal cell carcinoma before treatment with interleukin- 2 correlates with paraneoplastic syndromes but not patient survival. J Urol 159: 718-722, 1998.

22) Docci D, Bilancioni R, Buscaroli A, et al. Elevated serum levels of Creactive protein in hemodialysis patients. Nephron 56: 364-367, 1990.

23) Mclntyre C, Harper I, Macdougall IC, Raine AEG, Williams A, Baker LRI. Serum C-reactive protein as a marker for infection and inflammation in regular dialysis patients. Clin Nephrol 48: 371-374, 1997.

24) Naik RB, Gosling P, Price CP. Comparative study of alkaline phosphatase isoenzymes, bone histology, and skeletal radiography in dialysis bone disease. Br Med J 1: 1307-1310, 1977.

25) Herbelin A, Urena P, Nguyen AT, Zingraff J, Descamps-Latscha B. Elevated circulating levels of interleukin- 6 in patients with chronic renal failure. Kidney Int 39: 954-960, 1991.

26) Cavaillon JM, Poignet JL, Fitting C, Delons S. Serum interleukin-6 in long-term hemodialyzed patients. Nephron 60: 307-313, 1992.

27) Kaizu Y, Kimura M, Yoneyama T, Miyaji K, Hibi I, Kumagai H. Interleukin-6 may mediate malnutrition in chronic hemodialysis patients. Am J Kidney Dis 31: 93-100, 1998. 